\title{
Impact of industries in the accumulation of radionuclides in the lower part of Ebro river (Catalonia, Spain)
}

\author{
M. PALOMO ${ }^{1}$, A. PEÑALVER ${ }^{1}$, C. AGUILAR $^{1}$, F. BORRULL $^{1}$
}

(Manuscript received 18 March 2010, Accepted 10 May 2010)

ABSTRACT Ebro River extends over almost $930 \mathrm{~km}$ and is the main Spanish river entering the Mediterranean Sea. There are several industries located along this river course including a dicalcium phosphate factory (DCP) and two nuclear power reactors. These installations, together with other factors such as the geology, can contribute to the radiological content of the river. Therefore, this study was performed to determine some natural and also some anthropogenic radionuclide concentrations in the Ebro River ecosystem. We analysed water samples, solid samples (rice field sludge and surface marine sediment samples), and also biota samples (Cladophora glomerata and Cynodon dactylon). For water samples, gross alpha, gross beta, tritium, uranium, thorium and also a group of gamma-emitting isotopes' activities were determined. The main contribution to radioactivity for these samples was due to some isotopes from the uranium and thorium chain. For the solid samples, we quantified some natural and artificial gamma radioisotopes, which may be related to the geological and/or industrial activities located in this zone. In the case of biota, the results indicate that the presence of the DCP has a significant influence, since the highest activity was observed in the surroundings of this industry (Flix), where isotopes such as ${ }^{214} \mathrm{Bi}$ and ${ }^{214} \mathrm{~Pb}$ presented activity values of $105 \pm 43 \mathrm{~Bq} / \mathrm{kg}$ and $100 \pm 58 \mathrm{~Bq} / \mathrm{kg}$, respectively.

Keywords: Ebro River / natural and artificial radionuclides / biota samples / water

RÉSUMÉ Impact des industries dans l'accumulation de radionucléides dans le cours inférieur de l'Ėbre (Catalogne, Espagne).

L'Èbre s'étend sur une longueur de presque $930 \mathrm{~km}$ et est considéré comme le fleuve espagnol majeur se jetant dans la Méditerranée. Quelques industries se situent le long du cours du fleuve, comme par exemple une usine de phosphate dicalcique (DCP) ou deux réacteurs nucléaires. Ces installations, ainsi que d'autres facteurs comme la géologie, peuvent contribuer au contenu radiologique du fleuve. Dans ce sens, cette étude a été réalisée pour déterminer certaines concentrations de radionucléides d'origine naturelle ou anthropogénique dans l'écosystème de l'Èbre. Nous avons analysé des échantillons d'eau, des échantillons solides (des boues des rizières et des sédiments marins de surface) mais également des échantillons de biota (Cladophora glomerata et Cynodon dactylon). Pour les échantillons d'eau, l'activité brute des particules alpha et bêta a été déterminée, ainsi que celle du tritium, de l'uranium, du thorium et d'un groupe d'isotopes émetteurs gamma. La principale contribution, pour ces échantillons, à la radioactivité, a été due à quelques isotopes de la chaîne de l'uranium et du thorium. Pour les échantillons solides, nous avons

\footnotetext{
Unitat de Radioquímica Ambiental i Sanitaria, Universitat Rovira i Virgili, Consorci d'Aigues de Tarragona (CAT), Ctra. Nacional 340 km, 1094 Ap. correus n.7, 43895 L'Ampolla Tarragona, Spain.
} 
quantifié un certain nombre de radio-isotopes gamma naturels et artificiels, qui peuvent être en rapport avec les activités géologiques et/ou industrielles situées dans la région. Dans le cas du biote, les résultats indiquent que la présence de DCP a une forte influence car l'activité la plus importante a été observée dans la région dans laquelle se trouve celui-ci (Flix), ou des isotopes tels que le ${ }^{214} \mathrm{Bi}$ et le ${ }^{214} \mathrm{~Pb}$ ont des valeurs de $105 \pm 43 \mathrm{~Bq} / \mathrm{kg}$ et $100 \pm 58 \mathrm{~Bq} / \mathrm{kg}$, respectivement.

\section{Introduction}

Ebro River is one of the most important rivers in Spain, which discharges into the Mediterranean Sea after flowing through several large cities, towns and agricultural, mining and industrial areas. There are several industrial activities concentrated in the vicinity of the river which have caused contamination problems in the basin, and for this reason the study of the presence of different kinds of pollutants in Ebro river water is an issue of great concern, to evaluate the water quality and also the effects on the delta wildlife (Loureiro et al., 2009; Navarro et al., 2009).

Among the different contaminants that can be found in the river are the radionuclides, which can have a natural or anthropogenic origin. The presence of some of them can be attributed to the industrial activities developed in the Ebro River area. In particular, in the lower section of the river there is a Nuclear Power Plant (NPP), which comprises two pressurised-water reactor (PWR) units. As a result of the normal operation of this plant, low-level liquid radioactive effluents are discharged, under authority control, into the Ebro River, and they can reach the Mediterranean Sea (Sánchez-Cabeza and Molero, 2000). Also, close to the NPP there is a dicalcium phosphate (DCP) production factory located in Flix (Tarragona). This industry is responsible for the accumulation of sediments in the Flix reservoir (Ebro River) which derive from industrial waste dumped during the last decades until 1986. In recent years, these sediments have been characterised and they contain high concentrations of organic compounds, metals and natural radionuclides of the uranium decay series (Casacuberta et al., 2009).

Just before the river joins the sea, there is a delta of more than 30000 ha. This area is mainly focused on agriculture for rice crops but also for other kinds of crops, such as orchard and fruit trees. The area contains a network of irrigation and drainage channels devoted to rice farming. These irrigation channels bring water to the field, which is later collected by the drainage channels. The geology of the Ebro River area and the above-mentioned industrial activities suggest that the population could be exposed to different radioactivity sources. Based on this, the purpose of this study is to determine the natural or anthropogenic radioisotopes present in the lowest section of the river course by analysing water, sediments (rice 
field sludge from the Ebro Delta and surface marine sediments from the Mediterranean Sea from the area located in front of the Delta), and also biota samples (Cladophora glomerata and Cynodon dactylon).

\section{Experimental part}

\subsection{Procedures}

In the case of alpha-emitting isotopes different measurements were carried out depending on the sample matrix. In particular, for water samples we determined gross alpha activity and uranium and thorium isotopes, whereas for biota samples we determined only the isotopes of uranium and thorium alpha isotopes. To determine gross alpha activity we followed the method described previously by Palomo et al. (2007). The method consisted of taking aliquots of samples of $20 \mathrm{~mL}$, and then they were evaporated to dryness and the activity concentration was determined using a zinc sulphide (ZnS) scintillator counter (Canberra). To determine uranium and thorium isotope activities, the first step was based on a preconcentration in the case of water samples and an acidic digestion for biota samples. Then alpha isotopes were extracted with the tributyl phosphate (TBP) procedure, purified by BIORAD AG1-X8 resin to remove impurities, and finally, electroplated following the method reported in a previous paper by Palomo et al. (2010). The last step consisted of the activity measurement with an alpha spectrometer (EG\&G ORTEC).

For water samples, we also measured gross beta activity and tritium activity following the method described previously by Palomo et al. (2007). For gross beta activity, $250 \mathrm{~mL}$ of the sample was evaporated to dryness and the activity concentration was determined using a low background alpha/beta counter (Berthold). In the case of tritium a volume of $100 \mathrm{~mL}$ of sample was first distilled to remove impurities or other radionuclides and to reduce quenching. Then the distillation extract was mixed with the scintillation cocktail in a vial and measured by using a liquid scintillation counter (Quantulus 1220TM, Perkin Elmer).

Finally, for water samples, we also measured gamma emitters. To carry out this assay, a sample of $500 \mathrm{~mL}$ of water was filtered and then placed in a Marinelli beaker and measured $(72 \mathrm{~h})$ in a high-purity germanium detector (Canberra), equipped with a standard multi-channel analyser.

For sediments and biota samples we quantified a group of gamma emitter isotopes. For this purpose, the samples were dried in an oven at a temperature of $110^{\circ} \mathrm{C}$. Then, they were homogenised and a fraction was crushed in a ball mill and sifted in a sieve of $250 \mu \mathrm{m}$. Finally, $500 \mathrm{~g}$ of each sample were placed in a 


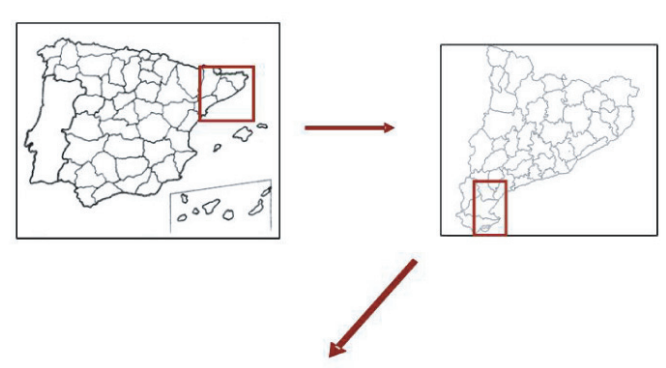

- biota samples

- sediment samples

$\Delta$ water samples
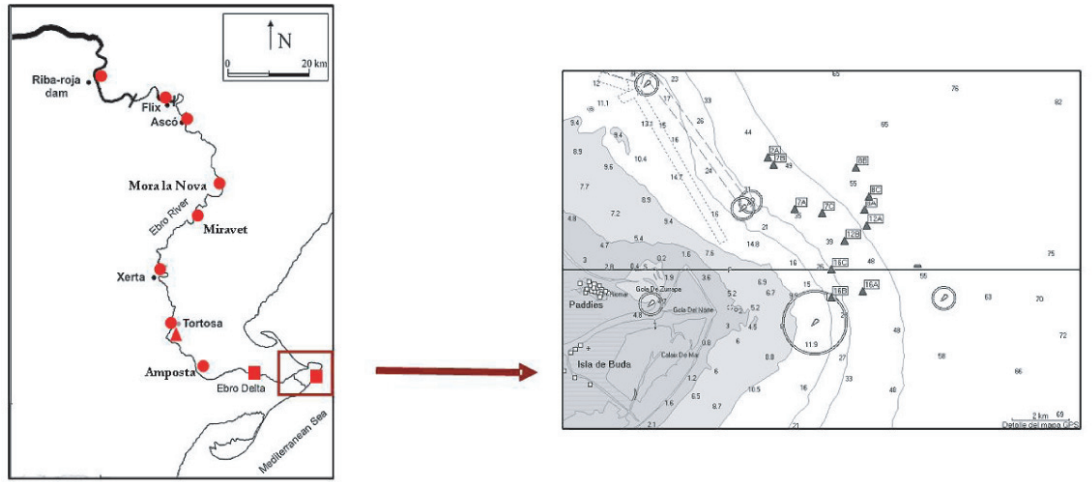

Figure 1 - Sampling points selected for this study. Ten points situated in the lower part of Ebro River from Riba-Roja de Ebro to the Ebro Delta area. In particular, we collected water samples from Camp-Redó (Tortosa) (•), sludge of rice fields, superficial sediments close to the sea and superficial marine sediments from the Ebro Delta area (๑). Also, we collected cladophora glomerata and Cynodon dactylon at eight points $(\bullet)$ along the Ebro River course.

Localisation des échantillons prélevés pour cette étude. Dix endroits sont situés dans la partie inférieure de l'Èbre, de Riba-Roja de Ebro à la zone du delta de l'Èbre. En particulier, les échantillons d'eau ont été prélevés à Camp-Redó (Tortosa) (•), la boue des rizières, les sédiments superficiels prés de la mer et les sédiments marins superficiels dans la zone du delta de l'Èbre (•). Enfin, des échantillons de Cladophora glomerata et de Cynodon dactylon ont été collectés en huit points (•) le long du cours de l'Èbre.

Marinelli beaker and measured $(20 \mathrm{~h})$ in a high-purity germanium detector (Canberra), equipped with a standard multi-channel analyser.

\subsection{Samples}

This study of the Ebro course environment covered $109 \mathrm{~km}$. In particular, we focused on the area comprised between the town Riba-Roja d'Ebro to the Ebro Delta area (see sampling points in Fig. 1). We collected three different sample matrices: water, solid material and biota. 
Water samples were taken monthly from Ebro River between January 2002 and December 2009. The water samples were collected from Camp-Redó (Tortosa, Catalonia, Spain). It has to be pointed out that the sampling point for these samples was located downstream of the area where some industries are situated. In particular, there are a dicalcium phosphate factory (DCP) in the town of Flix and a nuclear power plant with two reactor units in Ascó. These samples were collected in 2-L polyethylene bottles and stored until analysis at $4{ }^{\circ} \mathrm{C}$.

The solid samples included in this study were all from the Ebro Delta area and they can be classified into two types: (i) sludge samples from rice fields, which were provided by the Comunitat General de Regants del Canal de la Dreta de l'Ebre and were collected in May 2009 (when the rice fields were flooded with Ebro River water, before the rice was planted); and (ii) surface marine sediment samples from the Mediterranean Sea in front of the Ebro Delta area. In this case, the samples, collected on May 2009, were provided by the Studies on Marine Contamination group of the Instituto Español de Oceanografía (IEO, Spanish Oceanographic Institute) from Murcia (Spain).

Finally, biota samples were also analysed. In particular, we analysed two kinds of organisms: the first one was a characteristic freshwater alga, Cladophora glomerata, and the second one was a characteristic plant of the river bank, Cynodon dactylon. Both were taken from eight different points in the river course (see Fig. 1). The samples were collected in November 2008, March 2009 and July 2009.

\section{Results and discussion}

As has been pointed out before, the aim of this work was to determine the presence of different radioisotopes in the lower section of Ebro River through the analysis of different kinds of samples: water, biota and sediment samples.

\subsection{Water samples}

Table I shows the annual average activity values for gross alpha, gross beta, beta without ${ }^{40} \mathrm{~K}$ contribution and tritium obtained for the analysed water samples from Ebro River. River waters do not have to comply with any legislation regarding radioactive levels, but taking into account that this water is treated by a potable water treatment plant to be used as drinking water, we took as a reference the values established by the Spanish legislation for waters devoted to human consumption (Real Decreto, 2003). In particular, in this decree it is mandatory to control gross alpha activity, beta without ${ }^{40} \mathrm{~K}$ activity and also tritium activity. The maximum activity levels reported for these parameters in this law are $0.1 \mathrm{~Bq} / \mathrm{L}$, $1 \mathrm{~Bq} / \mathrm{L}$ and $100 \mathrm{~Bq} / \mathrm{L}$, respectively. 
TABLE I

Annual mean activity values of gross alpha, gross beta, gross beta without ${ }^{40} \mathrm{~K}$ and tritium of Ebro River water from 2002 to 2009 . The uncertainties were associated with the annual average activity values.

Activités moyennes annuelles en alpha brut, beta brut, beta sans ${ }^{40} \mathrm{~K}$ et en tritium dans l'eau de l'Èbre de 2002 à 2009. Les incertitudes ont été associées aux valeurs annuelles de l'activité moyenne.

\begin{tabular}{ccccccccc}
\hline year & \multicolumn{2}{c}{ Gross alpha } & \multicolumn{2}{c}{ Gross beta } & \multicolumn{2}{c}{$\begin{array}{c}\text { Gross beta } \\
\text { without }\end{array}$} \\
& $\mathbf{A}(\mathbf{B q} / \mathbf{L})$ & $\mathbf{u}$ & $\mathbf{A}(\mathbf{B q} / \mathbf{L})$ & $\mathbf{u}$ & $\mathbf{A}(\mathbf{B q} / \mathbf{L})$ & $\mathbf{u}$ & \multicolumn{2}{c}{ Tritium } \\
\hline 2002 & 0.08 & 0.04 & 0.18 & 0.02 & 0.07 & 0.02 & 2 & 0.2 \\
\hline 2003 & 0.05 & 0.02 & 0.09 & 0.02 & 0.02 & 0.02 & 2 & 0.8 \\
\hline 2004 & 0.07 & 0.03 & 0.14 & 0.03 & 0.04 & 0.03 & 9 & 7 \\
2005 & 0.07 & 0.02 & 0.08 & 0.03 & 0.03 & 0.02 & 5 & 4 \\
2006 & 0.07 & 0.03 & 0.13 & 0.02 & 0.03 & 0.02 & 11 & 8 \\
\hline 2007 & 0.06 & 0.03 & 0.15 & 0.03 & 0.03 & 0.02 & 6 & 3 \\
\hline 2008 & 0.09 & 0.05 & 0.19 & 0.05 & 0.05 & 0.04 & 10 & 1 \\
\hline 2009 & 0.10 & 0.04 & 0.14 & 0.03 & 0.10 & 0.06 & 50 & 10 \\
\hline
\end{tabular}

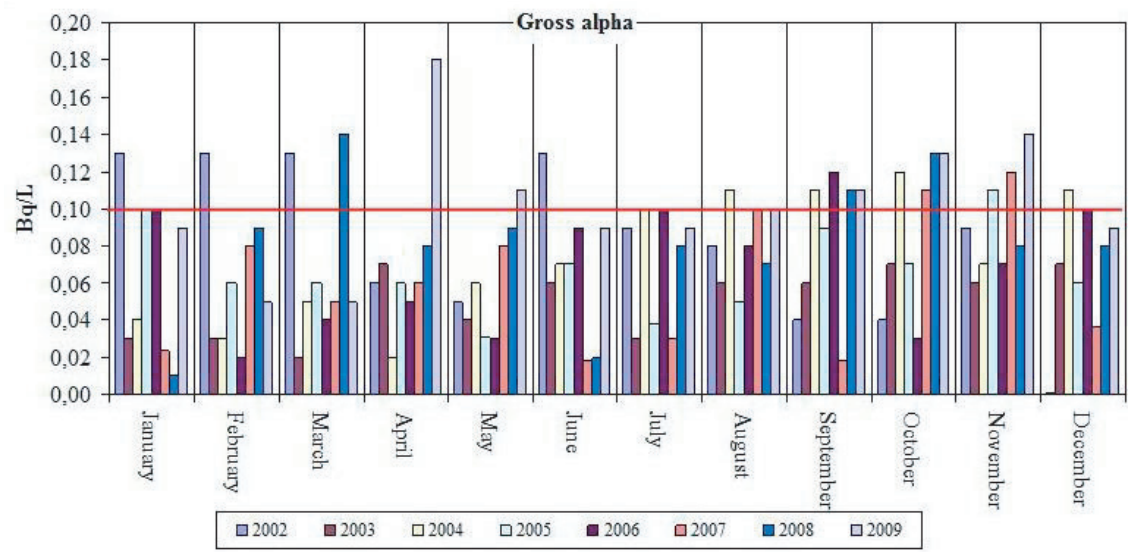

Figure 2 - Monthly activity values for gross alpha activities of Ebro River water from 2002 to 2009. Activités alpha brut mensuelles dans les eaux de l'Èbre de 2002 à 2009.

Figure 2 shows the monthly gross alpha activity values obtained for the period from 2002 to 2009 . As we can observe, some months displayed gross alpha activity values higher than the normative limit applied to drinking water $(0.1 \mathrm{~Bq} / \mathrm{L})$. However, for the samples analysed this is not problematic since this water must be treated by the potable water treatment plant (PWTP) located in the river course 
before it can be distributed for human consumption. Moreover, in a previous paper from our group (Palomo et al., 2010), we showed that the water treatment processes in this PWTP partially remove some of the alpha-emitting isotopes present in water at a percentage of $12-16 \%$ (for gross alpha activity) in comparison with untreated water.

On the other hand, in the same figure we can also observe a dispersion in the results $(<0.02-0.18 \mathrm{~Bq} / \mathrm{L})$, and this can be attributed to a combination of factors: in particular, to the presence of a dicalcium phosphate production factory and also to the river fluctuations. We can assess that due to previous activities of the DCP located in Flix, a mass of 350000 metric tons of residues is present in the water reservoir of Flix (Casacuberta et al., 2009). This waste is rich in heavy metals, radionuclides and organochlorine compounds, and the river course fluctuations during the year can produce a remobilisation of sediments accumulated in the Flix reservoir. Variations among the different periods evaluated can be attributed to this fact, since depending on the period of the year the river flux can vary. We can mention, for example, the data reported in the literature corresponding to the mean values obtained for Ebro River, in which it is stated that during summer months the mean flux was about $100 \mathrm{~m}^{3} / \mathrm{s}$ and this value increased to $500-700 \mathrm{~m}^{3} / \mathrm{s}$ during the rainy periods (CHE, 2009).

To confirm the possible influence of the presence of this industrial activity in the Ebro River samples, we compared the results obtained in this study with two other rivers situated in the north of Catalonia, Llobregat River and Ter River, which are not affected by these kinds of industries (NPP or DCP) but with a similar geological influence. We analysed a monthly sample of each river during 2009, and the average values obtained were $0.05 \pm 0.03 \mathrm{~Bq} / \mathrm{L}$ and $<0.02 \mathrm{~Bq} / \mathrm{L}$ for Llobregat River and Ter River, respectively. Despite the fact that these rivers belong to the same zone as Ebro River (Catalonia) we could observe a significant difference for the gross alpha activity values obtained for them. To study the possible origin of these differences, we performed a more exhaustive study to find a possible relationship between the reported activity values and the industrial activity. To do that, uranium, thorium and some gamma isotopes, which come from the ${ }^{238} \mathrm{U}$ decay chain (see Fig. 3), were evaluated for samples from the three rivers.

The average uranium activity values obtained for Ebro River water were $38 \pm 3 \mathrm{mBq} / \mathrm{L}$ and $32 \pm 3 \mathrm{mBq} / \mathrm{L}$, for ${ }^{234} \mathrm{U}$ and ${ }^{238} \mathrm{U}$, respectively. We also evaluated uranium activity for Llobregat River, and the average activities were $28 \pm 3 \mathrm{mBq} / \mathrm{L}$ and $20 \pm 3 \mathrm{mBq} / \mathrm{L}$ for ${ }^{234} \mathrm{U}$ and ${ }^{238} \mathrm{U}$, respectively, and in the case of Ter River the average values obtained were $16 \pm 2 \mathrm{mBq} / \mathrm{L}$ and $11 \pm 2 \mathrm{mBq} / \mathrm{L}$ for ${ }^{234} \mathrm{U}$ and ${ }^{238} \mathrm{U}$, respectively. Finally, ${ }^{230} \mathrm{Th}$ and ${ }^{232} \mathrm{Th}$ were also analysed and for 


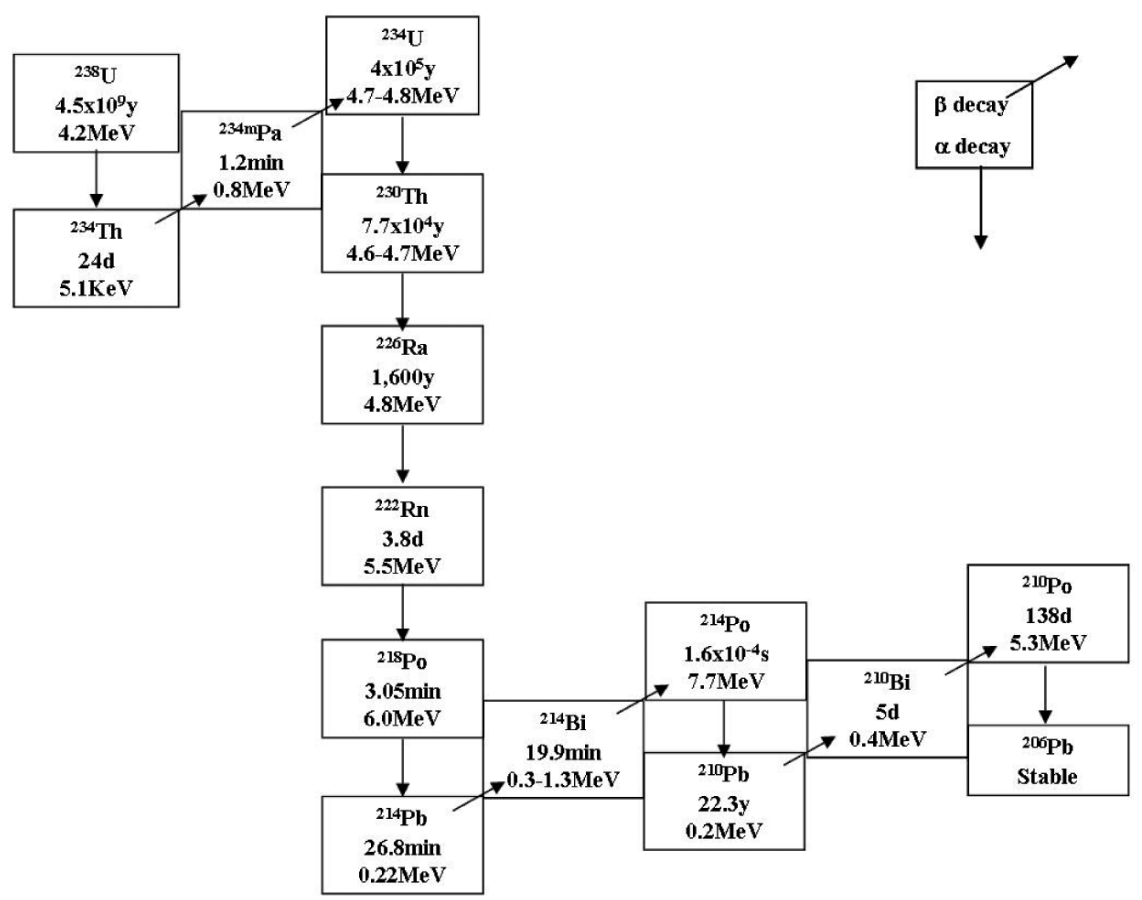

Figure 3 - The ${ }^{238} U$ decay chain showing the half-life and the characteristic emission energies for all its descendants.

La chaîne de décroissance de ${ }^{, 238} \mathrm{U}$ avec les demi-vies et les énergies d'émission caractéristiques de ${ }^{238} U$ et de chacun de ses descendants.

the three rivers the activity values were lower than the minimum detectable activity (MDA) $(0.09 \mathrm{mBq} / \mathrm{L}$ and $0.14 \mathrm{mBq} / \mathrm{L}$, respectively). The results obtained indicated that the activities found for uranium isotopes were slightly higher for Ebro River than for the other two rivers, although these differences do not explain the differences between the gross alpha activity values reported for the analysed samples. To verify the possible reason for this, we also evaluated the activity due to some gamma emitters. In this case, Ebro water was the only one which displayed activities over the MDA for ${ }^{214} \mathrm{Bi}$ and ${ }^{214} \mathrm{~Pb}$, with activity values of $1.8 \pm 0.8 \mathrm{~Bq} / \mathrm{L}$ and $0.5 \pm 0.1 \mathrm{~Bq} / \mathrm{L}$, respectively. These gamma emitters come from the ${ }^{238} \mathrm{U}$ decay chain. ${ }^{238} \mathrm{U}$, together with ${ }^{226} \mathrm{Ra}$, are the most abundant radionuclides accumulated in the Flix reservoir (Casacuberta et al., 2009). Our results are similar to those published by Bonotto and Bueno (2008). They estimated a mobility coefficient for ${ }^{226} \mathrm{Ra}$ in an aquifer 25 times higher than ${ }^{238} \mathrm{U}$ transported in the liquid phase. Also, these authors stated that the radioelement solubility in the system varies in the following 


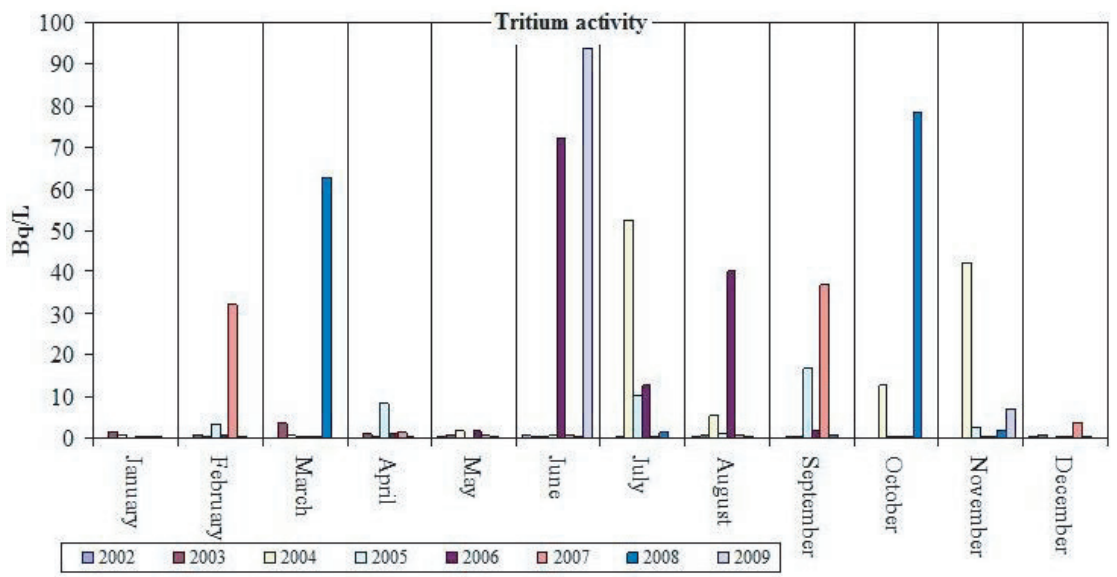

Figure 4 - Monthly activity values for tritium activities of Ebro River water from 2002 to 2009.

Activités mensuelles du tritium dans l'eau de l'Èbre de 2002 à 2009.

order: radium $>$ uranium $>$ thorium. Therefore, due to the high concentration of ${ }^{226} \mathrm{Ra}$ in Flix reservoir sediments, it is expected that it may be remobilised by the river fluctuations. This fact can explain the relatively high values found of gross alpha activity in Ebro water analysed with respect to the other two rivers.

No monthly significant differences were observed for the gross beta and gross beta without potassium activity values for the evaluated years: the average values obtained were $0.13 \pm 0.07 \mathrm{~Bq} / \mathrm{L}$ and $<0.04 \mathrm{~Bq} / \mathrm{L}$, respectively. The average activities for each year of the studied period are shown in Table I. In this case, the main contribution to gross beta activity is due to ${ }^{40} \mathrm{~K}$, which is highly soluble in water. Also, as in the case of gross alpha, we compared the results with those obtained for the other two rivers, Ter and Llobregat. The corresponding average values for Llobregat River were $1.1 \pm 0.05 \mathrm{~Bq} / \mathrm{L}$ and $<0.04 \mathrm{~Bq} / \mathrm{L}$, for gross beta and gross beta without potassium, respectively, and for Ter River the average activity values were $0.10 \pm 0.04 \mathrm{~Bq} / \mathrm{L}$ and $<0.04 \mathrm{~Bq} / \mathrm{L}$, respectively. Thus, for beta-emitting isotopes, no significant differences were observed for the three rivers.

In the case of tritium, it is important to remark that although it can have a natural origin, the presence of a NPP in the river course contributes to increasing the levels of this isotope in the evaluated area (Pujol and Sánchez-Cabeza, 1999; Baeza et al., 2002; Villa and Manjón, 2004). Thereby, tritium was quantified in almost all the measured Ebro River samples at higher levels than those reported for other rivers not affected by the presence of a NPP. We can observe in figure 4 the 
monthly tritium activity in the period studied for Ebro River water. The reported values for all the evaluated period showed variations which can be attributed to the controlled nuclear power plant discharges into the Ebro River (PVRA, 2007). Observing the results, we can remark that from 2004 until 2009, every year, two months have greater activities than the rest of the months. For example, in 2007, large activity values in February and September $(32 \pm 2 \mathrm{~Bq} / \mathrm{L}$ and $37 \pm 2 \mathrm{~Bq} / \mathrm{L}$, respectively) were obtained. These results are in agreement with the values reported by Pujol and Sánchez-Cabeza (1999) and Baeza et al. (2002) in previous studies about rivers affected by NPP. So, through the data obtained it can be concluded that the presence of the NPP in Ascó can be related to the tritium activity found in the Ebro River. Moreover, when we compared the results for tritium with the other two river water samples (Llobregat and Ter) the obtained values confirmed the influence of the Ascó NPP, since both rivers display values lower than our MDA $(<2 \mathrm{~Bq} / \mathrm{L})$. Contrary to the alpha emitters, tritium activity is more difficult to eliminate by the PWTP.

\subsection{Solid samples}

Radionuclides can be transported by the river water and remain finally accumulated in the Ebro Delta area or also penetrate into the Mediterranean Sea, into which the river flows (Loureiro et al., 2009; Navarro et al., 2009). To verify this, sludge samples from rice fields located in the Ebro Delta area and superficial marine sediments from the region located in front of the Delta were analysed (see Fig. 1). Table II shows the results obtained for the analysed solid samples.

As can be observed for these samples, the main contribution to the radioactivity is from natural isotopes, such as ${ }^{214} \mathrm{Bi},{ }^{214} \mathrm{~Pb},{ }^{210} \mathrm{~Pb},{ }^{212} \mathrm{Bi},{ }^{212} \mathrm{~Pb}$ and ${ }^{228} \mathrm{Ac}$. These isotopes belong to the natural decay chains of ${ }^{238} \mathrm{U}$ and ${ }^{232} \mathrm{Th}$. River water drags these metals from the Flix reservoir, so they are accumulated in sludge from Delta rice fields and superficial marine sediments from the Delta area.

Also, we could quantify ${ }^{40} \mathrm{~K}$ in all the collected samples. This isotope constitutes the main contribution to the radioactivity for these samples, with average activity values of $361 \pm 55 \mathrm{~Bq} / \mathrm{kg}$ and $639 \pm 66 \mathrm{~Bq} / \mathrm{kg}$ for rice field sludge and superficial marine sediments, respectively. In the case of rice field sludge, the relatively high activities for ${ }^{40} \mathrm{~K}$ can be related to the presence of salts and minerals of potassium. Their origin can be associated with the use of fertilisers for agricultural purposes and with other industrial activities, and in this case, the influence of the DCP located in Flix can be demonstrated. Gäfvert et al. (2001) reported that ${ }^{40} \mathrm{~K}$ concentrations are associated with impurities such as sand and clay which are removed from the phosphate rocks before the phosphate rock is delivered to the processing plant of the DCP. 
TABLE II

Mean activity values of gamma emitters found in the analysed soil samples: sludge from several rice fields and superficial marine sediments from the Ebro Delta area $(\mathrm{Bq} / \mathrm{kg}$ dry weight). The uncertainty is calculated using a confidence level of $95 \%(K=2)$.

Activités moyennes ( $\mathrm{Bq} / \mathrm{kg}$ poids sec) en émetteurs gamma mesurées dans les échantillons de sol analysés : boues de différentes rizières et sédiments marins superficiels de la zone du delta de

l'Èbre. L'incertitude est calculée en utilisant un intervalle de confiance de $95 \%$ (K=2).

\begin{tabular}{ccc}
\hline Radionuclides & $\begin{array}{c}\text { Sludge from Delta rice fields (n=10) } \\
\text { Activity (Bq/Kg dry weight) }\end{array}$ & $\begin{array}{c}\text { Marine sediments Delta (n=12) } \\
\text { Activity (Bq/Kg dry weight) }\end{array}$ \\
\hline${ }^{228} \mathrm{Ac}$ & $29 \pm 4$ & $35 \pm 3$ \\
${ }^{212} \mathrm{~Pb}$ & $28 \pm 3$ & $34 \pm 2$ \\
${ }^{212} \mathrm{Bi}$ & $17 \pm 2$ & $22 \pm 3$ \\
${ }^{208} \mathrm{Tl}$ & $9 \pm 1$ & $9 \pm 1$ \\
${ }^{214} \mathrm{~Pb}$ & $23 \pm 2$ & $21 \pm 1$ \\
${ }^{214} \mathrm{Bi}$ & $23 \pm 2$ & $22 \pm 2$ \\
${ }^{210} \mathrm{~Pb}$ & $32 \pm 6$ & $41 \pm 3$ \\
${ }^{40} \mathrm{~K}$ & $361 \pm 55$ & $639 \pm 66$ \\
${ }^{137} \mathrm{Cs}$ & $3 \pm 1$ & $4 \pm 1$ \\
\hline
\end{tabular}

$\mathrm{n}=$ number of samples analysed.

In the case of artificial radionuclides, we could quantify ${ }^{137} \mathrm{Cs}$ in all the analysed samples, and the average values obtained were: for samples from rice fields $3 \pm 1 \mathrm{~Bq} / \mathrm{kg}$ and, for superficial marine sediments $4 \pm 1 \mathrm{~Bq} / \mathrm{kg}$. For sludge samples from rice fields, the data obtained were in agreement with those reported by Navas et al. (2005) for cultivated soil from Spain's Pyrenees Mountains $(1.6-8.4 \mathrm{~Bq} / \mathrm{kg})$. The high dispersion of these values is due to the remobilisation and homogenisation of the cultivated soils. In the case of superficial marine sediments, the data obtained are also in good agreement with the data provided by Gascó et al. (2002) for surface marine sediment collected on the continental shelf adjacent to various areas in Catalonia. Gascó et al. (2002) reported values from surface marine sediments collected along the western Mediterranean shore: $6.4 \pm 1.5 \mathrm{~Bq} / \mathrm{kg}$ in Barcelona, $6.0 \pm 0.8 \mathrm{~Bq} / \mathrm{kg}$ in Tarragona, $3.3 \pm 0.5 \mathrm{~Bq} / \mathrm{kg}$ in Valencia, $4.3 \pm 0.7 \mathrm{~Bq} / \mathrm{kg}$ in Alicante and $2.7 \pm 0.5 \mathrm{~Bq} / \mathrm{kg}$ in Malaga. Moreover, it must be pointed out that in the paper of Gascó et al. (2002), they did not observe remarkable differences between the different sampling points evaluated. After analysing all the solid samples, we can confirm that caesium has its origin in the fallout inputs. 


\subsection{Biota samples from Ebro River course}

Table III shows the average activity values (Bq/kg dry weight) and the associated uncertainty obtained after quantifying gamma emitters in biota samples for the river section studied (see Fig. 1). We studied the radionuclide accumulation in some biota samples located in the river course. For this, we analysed two common species found in Ebro River: a green algae (Cladophora glomerata) and a bank grass (Cynodon dactylon).

In general, Cladophora glomerata displayed greater activity values than Cynodon dactylon for the measured isotopes. This difference can be observed mainly in the case of ${ }^{214} \mathrm{Bi}(105 \pm 43 \mathrm{~Bq} / \mathrm{kg})$ and ${ }^{214} \mathrm{~Pb}(100 \pm 58 \mathrm{~Bq} / \mathrm{kg})$ in the samples collected in Flix, as is shown in Figure 5. The origin of such radioisotopes can be attributed to radium: as we commented in the water section (see Sect. 3.1), ${ }^{226} \mathrm{Ra}$ enters into the surface water and it is absorbed by the algae. These metals are dragged along the river water and accumulate in the river bed. The ${ }^{226} \mathrm{Ra}$ from the Flix reservoir sludge remains in solution and enters the surface water as a soluble compound $\left({ }^{226} \mathrm{RaCl}_{2}\right)$, hence it is absorbed by the river ecosystem, which is in direct contact with the water.

For samples which present high activity values of ${ }^{214} \mathrm{Bi}$ and ${ }^{214} \mathrm{~Pb}$ (two bank grass samples from Ascó and Tortosa, and two green algae samples from Flix), we analysed uranium and thorium isotopes since ${ }^{214} \mathrm{Bi}$ and ${ }^{214} \mathrm{~Pb}$ originate in the natural decay chain of ${ }^{238} \mathrm{U}$ (see Fig. 3). Figure 6 shows the activity values for uranium and thorium isotopes found in the evaluated samples. No significant differences were observed between the two biological samples analysed for uranium. However, ${ }^{230} \mathrm{Th}$ has a greater concentration in green algae samples than in bank grass samples. This radionuclide is generated in solution by radioactive decay of the soluble ${ }^{234} \mathrm{U}$, which is an isotope also originating in the ${ }^{238} \mathrm{U}$ decay chain (see Fig. 3).

The activity for ${ }^{40} \mathrm{~K}$ was clearly higher for green algae and bank grass (265-1343 Bq/kg dry weight) samples than the activity due to the other natural radionuclides found. Potassium has a high affinity for soil, so the concentration associated with soil particles is in general higher than in the interstitial water; therefore it enters in contact with the biota, which absorbs all the salts and minerals of the soil (Shaban, 2004).

Finally, we found some artificial radionuclides in these samples. The green algae display activities over the MDA for ${ }^{60} \mathrm{Co}(3.1-11 \mathrm{~Bq} / \mathrm{kg})$ and ${ }^{110 \mathrm{~m}} \mathrm{Ag}$ $(1.1-2.1 \mathrm{~Bq} / \mathrm{kg})$. Both radionuclides are by-products of nuclear reactor operations; ${ }^{60} \mathrm{Co}$ is produced when metal structures, such as steel rods, are exposed to neutron 


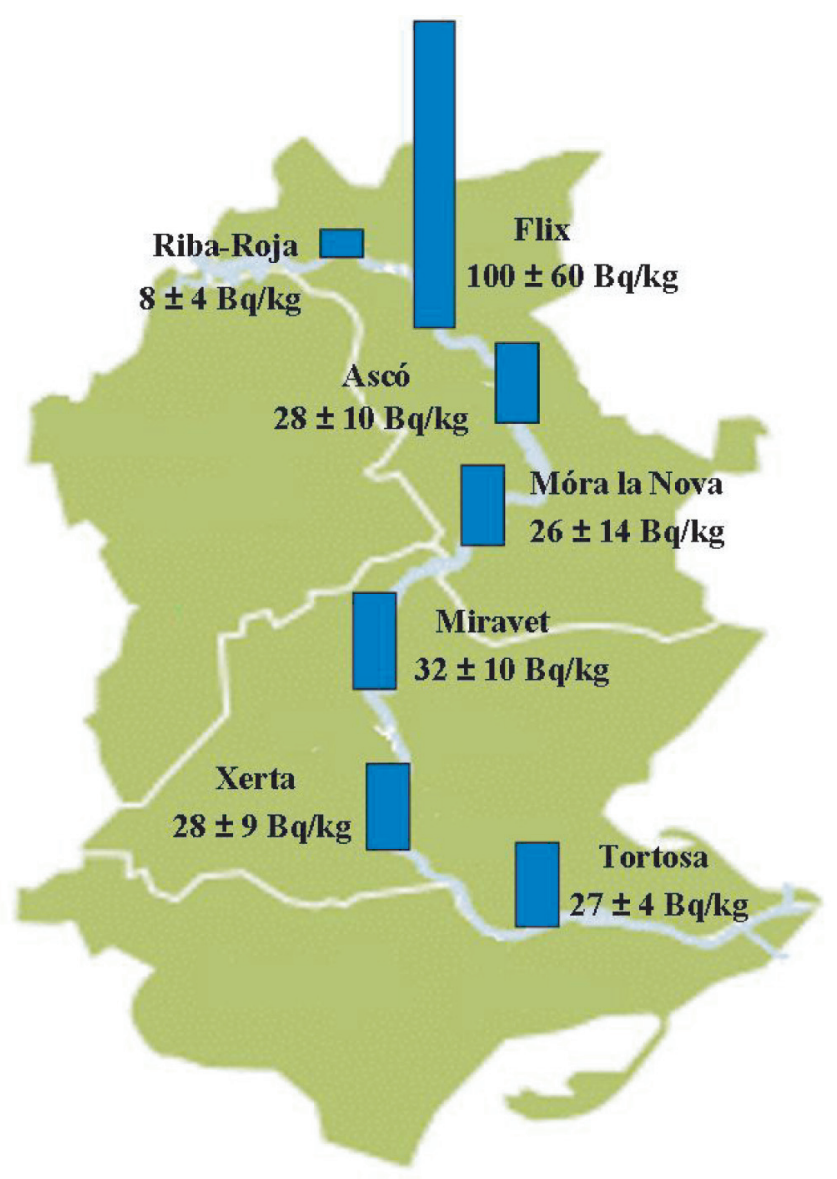

Figure $5-{ }^{214} \mathrm{~Pb}$ levels of cladophora glomerata samples from the Ebro River course.

Teneurs en ${ }^{214} \mathrm{~Pb}$ dans les échantillons de Cladophora glomerata prélevés le long du cours de l’èbre.

radiation, and ${ }^{110 \mathrm{~m}} \mathrm{Ag}$ is produced due to silver-109 neutron activation. Our results agree with those reported annually by the Spanish National Security Council (CSN). The environmental nuclear monitoring programme published in Spain since 2001 also reports that ${ }^{110 \mathrm{~m}} \mathrm{Ag}$ is found in aquatic plants in the surroundings of the nuclear power plant of Ascó (Tarragona, Spain) from $0.1-1.4 \mathrm{~Bq} / \mathrm{kg}$. These artificial radionuclides have their origin in the discharges of the nuclear power plant situated in the Ebro River, since they were only detected at the lower sample points, after the NNP (PVRA, 2007). For all the biota samples analysed the activity values for ${ }^{137} \mathrm{Cs}$ were lower than the MDA. 


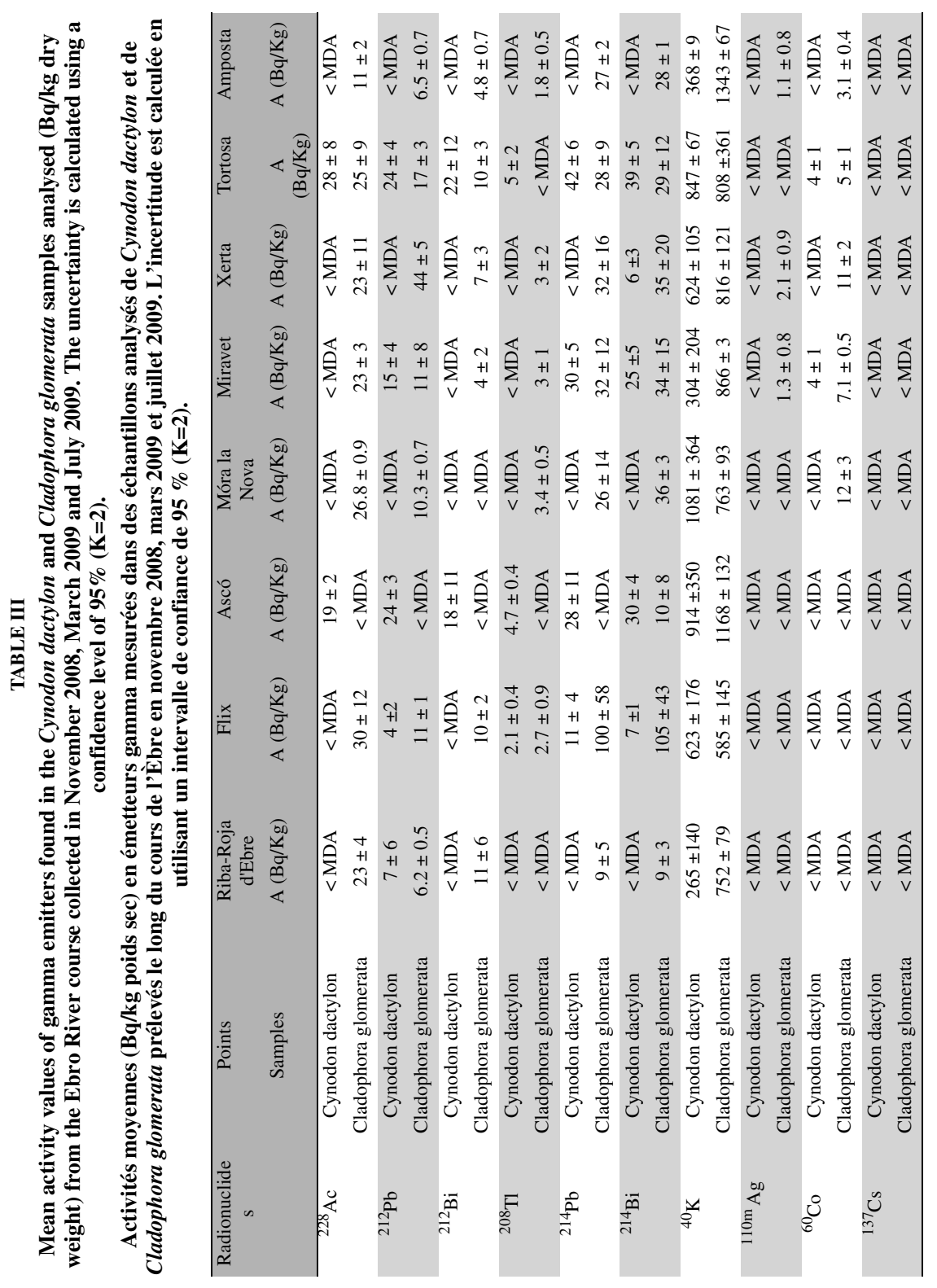




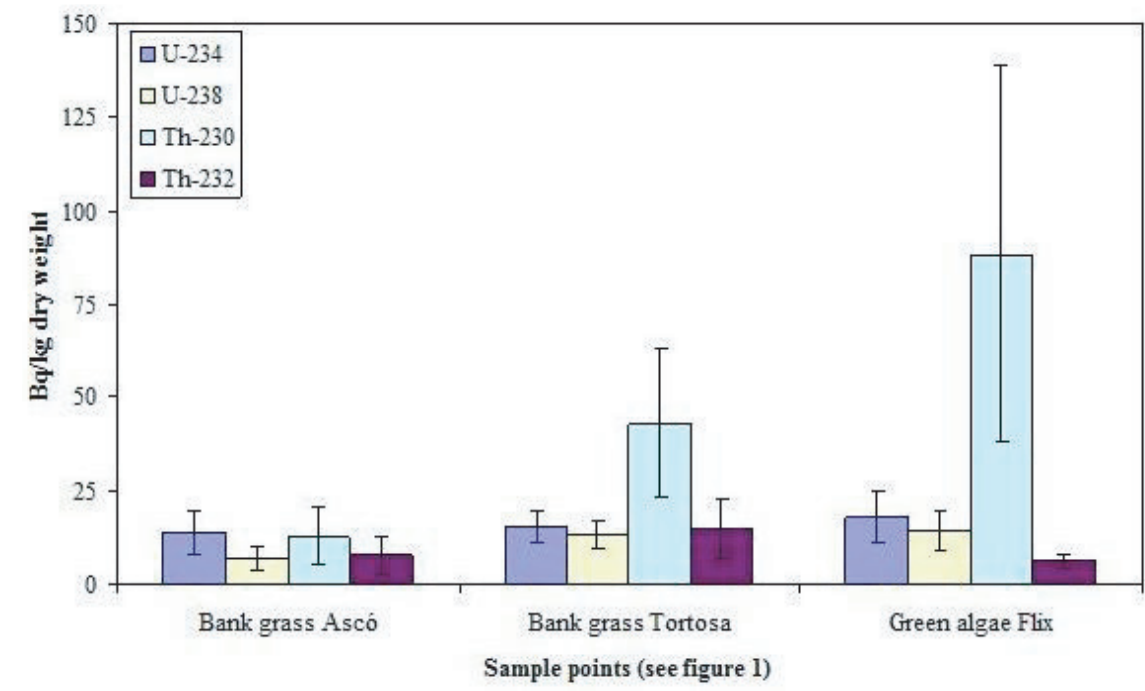

Figure 6 - Uranium and thorium isotope activity values of green algae and bank grass for the samples which displayed a great ${ }^{214} \mathrm{~Pb}$ and ${ }^{214} \mathrm{Bi}$ concentration.

Activité des isotopes de l'uranium et du thorium dans les algues vertes et l'herbe des berges issues d'échantillons ayant montré une forte concentration en ${ }^{214} \mathrm{~Pb}$ et en ${ }^{214} \mathrm{Bi}$.

\section{Conclusions}

Ebro River presented significant levels of gross alpha activities in some months over the eight-year period studied. Nevertheless, this water was treated in a PWTP previously to being supplied as drinking water and the PWTP processes have the capacity to eliminate $12-16 \%$ of gross alpha activity present in the raw water. Therefore, the water supplied by this PWTP complies with the parameters established by the normative standards for drinking water.

For the solid samples collected, sediments from the Ebro Delta area and sea sediments in front of the river, we did not obtain remarkable values of the radionuclides analysed. Therefore, it can be concluded that the industrial activities of Ebro River do not significantly influence these kinds of samples.

The river algae have the capacity to concentrate some radionuclides, as was observed in the samples collected in the Flix reservoir, which displayed high values of ${ }^{214} \mathrm{Bi}$ and ${ }^{214} \mathrm{~Pb}$ in comparison with the other samples collected in the Ebro river course. These values are in agreement with the high gross alpha 
activities observed in some months for water samples and could be related to the possible remobilisation of the Flix residues.

Acknowledgments. The authors would like to thank the Instituto Español de Oceanografía (IEO, Spanish Oceanographic Institute) for its collaboration and providing us with sediment samples. Also, we appreciate the collaboration of the Comunitat General de Regants del Canal de la Dreta de l'Ebre, which provided us with the sludge from the rice fields of the Ebro Delta area. Finally, we would like to thank especially the Consorci d'Aigües de Tarragona (CAT) for its collaboration during the realisation of this study.

\section{REFERENCES}

Baeza A., Díaz M., García E., Miró C. (2002) Influence of interbasin transfers between the Alcantara and Guadiloba reservoirs on the radiological quality of the drinking water of the city of Caceres (Spain), Journal of Radioanalytical Nuclear Chemistry 252, 441-449.

Bonotto D.M., Bueno T.O. (2008) The natural radioactivity in Guarani aquifer groundwater, Brazil, Applied Radiation and Isotopes 66, 1507-1522.

Casacuberta N., Masqué P., Garcia-Orellana J., Bruach J.M., Anguita M., Gasa J., Villa M., Hurtado S., Garcia-Tenorio R. (2009) Radioactivity contents in dicalcium phosphate and the potential radiological risk to human populations, Journal of Hazardous Materials 170, 814-823.

CHE (2009) Confederación Hidrográfica del Ebro, December 2009, http://www.chebro.es.

Gäfvert T., Holm E., Roos P. (2001) Radionuclide fluxes at a plant manufacturing dicalcium phosphate for domestic animals, Journal of Environmental Radioactivity 54, 61-73.

Gascó C., Antón M.P., Pozuelo M., Meral J., González A.M., Papucci C., Delfanti R. (2002) Distributions of $\mathrm{Pu}, \mathrm{Am}$ and $\mathrm{Cs}$ in margin sediments from the western Mediterranean (Spanish coast), Journal of Environmental of Radioactivity 59, 75-89.

Loureiro S., Garcé E., Fernández-Tejedor M., Vaqué D., Camp J. (2009) Pseudonitzschia spp. (Bacillariophyceae) and dissolved organic matter (DOM) dynamics in the Ebro Delta (Alfacs Bay, NW Mediterranean Sea), Estuarine, Coastal and Shelf Science 83, 539-549.

Navas A., Machín J., Soto J. (2005) Mobility of natural radionuclides and selected major and trace elements along a soil toposequence in the Central Spanish Pyrenees, Soil Science 170, 743-757.

Navarro A., Quirós L., Casado M., Faria M., Carrasco L., Benejam L.L., Benito J., Díez S., Raldúa D., Barata C., Bayona J.M., Piña B. (2009) Physiological responses to mercury in feral carp populations inhabiting the low Ebro River (NE Spain), a historically contaminated site, Aquatic Toxicology 93, 150-157.

Palomo M., Peñalver A., Borrull F., Aguilar C. (2007) Measurement of radioactivity in bottled drinking water in Spain, Applied Radiation and Isotopes 65, 1165-1172.

Palomo M., Peñalver A., Aguilar C., Borrull F. (2010) Radioactivity evaluation of Ebro River water and sludge treated in a potable water treatment plant located in the south of Catalonia (Spain), Applied Radiation and Isotopes 68, 474-480.

Pujol L.L., Sánchez-Cabeza J.A. (1999) Optimisation of liquid scintillation counting conditions for rapid tritium determination in aqueous samples, Journal of Radioanalytical Nuclear Chemistry 242, 391-398.

PVRA (2007) Programa de Vigiláncia Radiológica Ambiental, Colección de Informes Técnicos 28.2008. Madrid. 


\section{IMPACT OF INDUSTRIES IN THE ACCUMULATION OF RADIONUCLIDES}

Real Decreto 140/2003 (2003) Boletín Oficial del Estado n.45, 21 de Febrero del 2003, 72287245.

Sánchez-Cabeza J.A., Molero J. (2000) Plutonium, Americium and radiocaesium in the marine environment close to the Vandellós I nuclear power plan before decommissioning, Journal of Environmental Radioactivity 51, 211-228.

Shaban M.H. (2004) Doctoral Thesis, On the human radiation exposure as derived from the analysis of natural and man-made radionuclides in soils, Universität Hannover, Hannover.

Villa M., Manjón G. (2004) Low-Level measurements of tritium in water, Applied Radiation and Isotope 61, 319-323. 